\title{
Protective Activity of Silipide on Liver Damage in Rodents
}

\author{
Marisa Conti, Salvatore Malandrino and Maria Josè Magistretti \\ Inverni della Beffa Research and Development Laboratories, via Ripamonti 99, Milan, Italy \\ Received May 18, 1992 Accepted August 6, 1992
}

\begin{abstract}
The activity of silipide, a silybin-phosphatidylcholine complex (IdB 1016), was tested in different models of liver damage in rodents. After oral administration, silipide exhibited a significant and dose-related protective effect against the hepatotoxicity induced by $\mathrm{CCl}_{4}$, praseodymium, ethanol and galactosamine. The $\mathrm{ED}_{50}$ values for inhibition of the rise in ASAT and ALAT levels caused by $\mathrm{CCl}_{4}$ and praseodymium and for antagonism of the increase in liver triglycerides caused by ethanol ranged from 93 to $156 \mathrm{mg} / \mathrm{kg}$ (as silybin). At a dose of $400 \mathrm{mg} / \mathrm{kg}$ (as silybin), silipide was also active in protecting against paracetamol-induced hepatotoxicity. Silybin and phosphatidylcholine at doses equivalent to those contained in the active doses of silipide failed to show any significant protective activity in these models. The liver protective effect of silipide is probably related to its antioxidant activities and to a stimulating effect on the hepatic synthesis of RNA and proteins.
\end{abstract}

Keywords: Silybin, Silipide (IdB 1016), Hepatic intoxication, Flavonoids, Liver protective activity

Silybin is the main active flavonolignan constituent of silymarin, a purified extract from the seeds of Silybum marianum widely used for the treatment of hepatic disorders (1).

The pharmacological activity of silybin has been established in vitro in cultured hepatocytes and in vivo after parenteral administration (2-6). Silybin has also been reported to exhibit a scavenging and antiperoxidative activity as well as a stimulating effect on RNA polymerase I, with consequent enhancement of liver protein biosynthesis $(7,8)$. These properties can explain its protective effects in some experimental models of liver damage such as the hepatotoxicity induced by $\mathrm{CCl}_{4}$, paracetamol and praseodymium.

When given by the oral route, silybin exhibits a low bioavailability $(9,10)$. Its complexation with phosphatidylcholine in a 1:1 molar ratio gives rise to silipide* (laboratory code IdB 1016, average molecular weight: 1260), a compound endowed with higher lipophilicity (11). Morazzoni et al. (12) demonstrated that after oral administration of silipide to rats, the plasmatic and the biliary levels of silybin were significantly higher than those obtaincd after administration of uncomplexed silybin.

The aim of the present study was to assess the effect of silipide against liver damage induced by different agents such as $\mathrm{CCl}_{4}$, praseodymium, ethanol, galactosamine and paracetamol, in comparison with the components of the complex, silybin and phosphatidylcholine.

\section{MATERIALS AND METHODS}

Animals

Male and female Sprague-Dawley rats, male Wistar rats and female Swiss mice were purchased from Nossan S.r.l. (Correzzana, Italy) and housed in air conditioned rooms at $21 \pm 1^{\circ} \mathrm{C}$, with free access to food (TR-M. Nossan) and water.

The animals were deprived of food but allowed free access to water for $16-24 \mathrm{hr}$ before sacrifice.

Blood was withdrawn under ether light anesthesia. The animals were killed by an overdose of ether.

\section{Test compounds}

Silipide (purity grade $>97 \%$ ) and silybin were from Inverni della Beffa Research and Development Laboratories. Phosphatidylcholine was purchased from Sigma. The test compounds were suspended in water and given by gastric gavage at a volume of $10 \mathrm{ml} / \mathrm{kg}$ to rats and $20 \mathrm{ml} / \mathrm{kg}$ to mice.

\footnotetext{
${ }^{*}$ proposed INN
} 


\section{Materials}

Carbon tetrachloride $\left(\mathrm{CCl}_{4}\right.$, Rudi Pont), ethanol (Rudi Pont), praseodymium nitrate pentahydrate ( $\mathrm{Pr}$, Fluka), paracetamol (Sigma), D-galactosamine hydrochloride (GalN, Merck), D-glucose, sodium chloride, methanol, chloroform (Merck), mineral oil (Sigma), ethyl ether (C. Erba) were used.

Biochemical analyses were performed by standard methods (Boehringer).

\section{Experimental proceedings}

Preliminary studies have been performed for each method in order to choose the best experimental conditions and the most suitable range of silipide doses. In the present paper, only the final experiments are reported.

\section{Carbon tetrachloride-induced damage in rats}

$\mathrm{CCl}_{4}(3 \mathrm{ml} / \mathrm{kg}$ of a $20 \%$ solution in mineral oil) was given by gastric gavage to male Sprague-Dawley rats weighing $200-220 \mathrm{~g}$. The dose of $\mathrm{CCl}_{4}(0.6 \mathrm{ml} / \mathrm{kg})$ was in the range of the doses reported by Torielli and Ugazio (13).

Test compounds or water were given by gastric gavage to groups of 20 rats once daily for three consecutive days, the first dose being administered $24 \mathrm{hr}$ before $\mathrm{CCl}_{4}$. A group of water-treated rats, used as non-intoxicated controls, received $3 \mathrm{ml} / \mathrm{kg}$, p.o. of mineral oil instead of $\mathrm{CCl}_{4}$.

Liver damage was evaluated $30 \mathrm{hr}$ after $\mathrm{CCl}_{4}$ administration by determining serum aspartate and alanine amino transferase (ASAT and ALAT) activities.

\section{Praseodymium-induced liver damage in rats}

$\operatorname{Pr}(10 \mathrm{mg} / \mathrm{kg}$ dissolved in $0.9 \% \mathrm{NaCl}$ solution) was injected intravenously to male Wistar rats weighing $320-370 \mathrm{~g}$, according to Strubelt et al. (5).

Test compounds or water were given by gastric gavage at the same time as $P r$ to groups of 12 rats. A group of water-treated rats received $1 \mathrm{ml} / \mathrm{kg}$ (i.v.) of saline instead of Pr.

Liver damage was evaluated 48 hr later by determining serum ASAT and ALAT activities, liver weight and hepatic triglycerides after Folch extraction (14).

\section{Ethanol-induced liver damage in rats}

Ethanol $(6 \mathrm{~g} / \mathrm{kg}$ as a $40 \%$ aqueous solution $\mathrm{w} / \mathrm{v})$ was given by gastric gavage to female Sprague-Dawley rats weighing $180-200 \mathrm{~g}$, according to Baraona and Lieber (15).

Test compounds or water were given by gastric gavage to groups of 10 rats, twice daily for two days and once on the third day, the last dose being given $1 \mathrm{hr}$ be- fore ethanol administration. Two additional groups of rats received, instead of ethanol or water, $15 \mathrm{ml} / \mathrm{kg}$ of a solution of glucose isocaloric with ethanol.

Liver damage was evaluated $24 \mathrm{hr}$ after ethanol administration by determining serum triglycerides, liver weight and hepatic triglycerides.

\section{Galactosamine-induced liver damage in rats}

GalN ( $500 \mathrm{mg} / \mathrm{kg}$ dissolved in saline) was injected intraperitoneally to female Sprague-Dawley rats weighing $220-240 \mathrm{~g}$, according to Pickering et al. (16).

Test compounds or water were given by gastric gavage $4 \mathrm{hr}$ before and $4 \mathrm{hr}$ after GalN to groups of 12 rats. A group of water-treated rats received $2 \mathrm{ml} / \mathrm{kg}$ (i.p.) of saline instead of GalN.

Liver damage was evaluated $24 \mathrm{hr}$ after GalN by determining serum ASAT and ALAT activities.

\section{Paracetamol-induced liver damage in mice}

Paracetamol ( $400 \mathrm{mg} / \mathrm{kg}$ suspended in saline) was injected intraperitoneally to female mice weighing 20-24 $\mathbf{g}$, according to Hjelle et al. (17). The mice were chosen since they are more susceptible than rats to hepatic damage induced by paracetamol (18).

Test compounds or water $(20 \mathrm{ml} / \mathrm{kg})$ were given by gastric gavage to groups of 20 mice $1 \mathrm{hr}$ before paracetamol injection. A group of water-treated mice received $10 \mathrm{ml} / \mathrm{kg}$, i.p. of saline instead of paracetamol.

Liver damage was evaluated $48 \mathrm{hr}$ after paracetamol by determining serum ASAT and ALAT activities.

\section{Statistical analyses}

Data were expressed as the mean \pm S.E. When a homogeneity of variances was found in Bartlett's test, the statistical significance of differences was evaluated by ANOVA, and differences between the control and treated groups were evaluated by Dunnett's $t$-test or Duncan's multiple range test.

When data showed heterogeneity of variances, Kruskal-Wallis non parametric ANOVA and Dunn's $t$-test were used.

$\mathrm{ED}_{50}$ values were calculated by interpolation when significant $\log$ dose-effect relationships were found in the least square or weighed least square regression analysis.

\section{RESULTS}

\section{Effect against $\mathrm{CCl}_{4}$-induced liver damage in rats}

Oral administration of $\mathrm{CCl}_{4}$ in rats induced a significant increase in serum ASAT and ALAT activities in comparison with the controls.

Silipide given by gastric gavage at doses of $25,82.5$ 
and $250 \mathrm{mg} / \mathrm{kg}$ (as silybin) once daily for three consecutive days showed a dose-related protective activity (Table 1). ED 50 values (expressed as silybin) were 105 $(56-142) \mathrm{mg} / \mathrm{kg}$ for ASAT and $132(66-185) \mathrm{mg} / \mathrm{kg}$ for ALAT.

Silybin ( 25 and $250 \mathrm{mg} / \mathrm{kg}$ ) and phosphatidylcholine $(400 \mathrm{mg} / \mathrm{kg}$, which is equivalent to the amount present in a dose of the complex containing $250 \mathrm{mg}$ of silybin) did not show any significant protective activity.

\section{Effect against praseodymium-induced liver damage in rats}

Intravenous injection of Pr induced severe liver damage, as indicated by significant increases in ASAT,
ALAT and hepatic triglycerides.

Single doses of silipide (100 to $800 \mathrm{mg} / \mathrm{kg}$, as silybin), given by gastric gavage at the same time as Pr, significantly reduced serum transaminase activities in a doserelated manner (Table 2). $\mathrm{ED}_{50}$ values (expressed as silybin) were $93(27-166) \mathrm{mg} / \mathrm{kg}$ for ASAT and 156 $(52-240) \mathrm{mg} / \mathrm{kg}$ for A.LAT. At doses of 400 and 800 $\mathrm{mg} / \mathrm{kg}$, silipide also reduced significantly the accumulation of triglycerides in the liver by about $60 \%$.

Silybin $(100$ or $800 \mathrm{mg} / \mathrm{kg}$ ) did not show any protective activity against Pr-induced liver damage.

Phosphatidylcholine, up to a dose of $320 \mathrm{mg} / \mathrm{kg}$ (which is higher than that contained in the $\mathrm{ED}_{50}$ of the complex), was also devoid of activity in the same model.

Table 1. Effects of silipide, silybin and phosphatidylcholine against $\mathrm{CCl}_{4}$-induced liver damage in rats

\begin{tabular}{|c|c|c|c|c|c|}
\hline \multirow{3}{*}{ Treatment } & \multirow{3}{*}{$\begin{array}{c}\text { Dose } \\
\mathrm{mg} / \mathrm{kg} \times 3 \\
\text { p.o. }\end{array}$} & \multicolumn{4}{|c|}{ Serum enzymes } \\
\hline & & \multicolumn{2}{|c|}{ ASAT } & \multicolumn{2}{|c|}{ ALAT } \\
\hline & & $\mathrm{U} / 1$ & $E D_{s 0} \mathrm{mg} / \mathrm{kg}$ & $\mathrm{U} / 1$ & $\mathrm{ED}_{50} \mathrm{mg} / \mathrm{kg}$ \\
\hline Controls & - & $87.2 \pm 3.9^{* *}$ & & $22.0 \pm 1.2^{* *}$ & \\
\hline $\mathrm{CCl}_{4}$ & - & $335.1 \pm 38.3$ & & $123.9 \pm 19.8$ & \\
\hline \multirow[t]{3}{*}{ Silipide (as silybin) $+\mathrm{CCl}_{4}$} & 25 & $300.0 \pm 55.0$ & & $127.3 \pm 30.9$ & \\
\hline & 82.5 & $238.0 \pm 24.3$ & 105 & $89.7 \pm 13.0$ & 132 \\
\hline & 250 & $145.1 \pm 10.8^{* *}$ & $(56-142)$ & $51.5 \pm 6.4^{*}$ & $(66-185)$ \\
\hline \multirow[t]{2}{*}{ Silybin $+\mathrm{CCl}_{4}$} & 25 & $261.9 \pm 31.1$ & & $97.3 \pm 16.3$ & \\
\hline & 250 & $249.8 \pm 34.1$ & & $107.3 \pm 21.4$ & \\
\hline Phosphatidylcholine $+\mathrm{CCl}_{4}$ & 400 & $233.5 \pm 29.5$ & & $94.6 \pm 14.7$ & \\
\hline
\end{tabular}

Test compounds were given by gastric gavage to rats once daily for 3 consecutive days starting 24 hr before administration of $\mathrm{CCl}_{4}\left(3 \mathrm{ml} / \mathrm{kg}\right.$ of a $20 \%$ solution in mineral oil, p.o.). Liver damage was evaluated $30 \mathrm{hr}$ after $\mathrm{CCl}_{4}$. Each value represents the mean $\pm \mathrm{S}$.E. for 20 rats. ${ }^{*} \mathrm{P}<0.05,{ }^{* *} \mathrm{P}<0.01$ vs. $\mathrm{CCl}_{4}$ group, Dunnett's $t$-test. The doses producing a $50 \%$ reduction (ED 50 values) of the rise in ASAT and ALAT were interpolated from log dose-effect plots calculated by weighed least squares regression. Numbers in brackets indicate $95 \%$ confidence limits.

Table 2. Effects of silipide, silybin and phosphatidylcholine against praseodymium (Pr) induced liver damage in rats

\begin{tabular}{|c|c|c|c|c|c|}
\hline \multirow{3}{*}{ Treatment } & \multirow{3}{*}{$\begin{array}{c}\text { Dose } \\
\mathrm{mg} / \mathrm{kg} \\
\text { p.o. }\end{array}$} & \multicolumn{4}{|c|}{ Serum enzymes } \\
\hline & & \multicolumn{2}{|c|}{ ASAT } & \multicolumn{2}{|c|}{ ALAT } \\
\hline & & $\mathrm{U} / 1$ & $\mathrm{ED}_{50} \mathrm{mg} / \mathrm{kg}$ & $\mathrm{U} / \mathrm{l}$ & $\mathrm{ED}_{\mathrm{so}} \mathrm{mg} / \mathrm{kg}$ \\
\hline Controls & - & $114.0 \pm 5.9^{* *}$ & & $28.2 \pm 1.1^{* *}$ & \\
\hline $\operatorname{Pr}$ & - & $2070.0 \pm 273.6$ & & $1842 \pm 380.0$ & \\
\hline \multirow[t]{4}{*}{ Silipide (as silybin) $+\operatorname{Pr}$} & 100 & $1470.7 \pm 375.3$ & & $1428.5 \pm 430.7$ & \\
\hline & 200 & $649.2 \pm 118.3$ & & $725.0 \pm 163.1$ & \\
\hline & 400 & $463.3 \pm 147.7^{* *}$ & 93 & $447.0 \pm 190.4^{* *}$ & 156 \\
\hline & 800 & $186.1 \pm 16.2^{* *}$ & $(27-166)$ & $77.3 \pm 8.2^{* *}$ & $(52-240)$ \\
\hline \multirow[t]{2}{*}{ Silybin $+\operatorname{Pr}$} & 100 & $3728.3 \pm 606.6$ & & $3410.0 \pm 669.1$ & \\
\hline & 800 & $2912.4 \pm 740.2$ & & $1901.8 \pm 433.9$ & \\
\hline \multirow[t]{2}{*}{ Phosphatidylcholine $+\operatorname{Pr}$} & 160 & $2036.7 \pm 435.2$ & & $2296.7 \pm 565.9$ & \\
\hline & 320 & $1441.7 \pm 260.5$ & & $1498.3 \pm 235.6$ & \\
\hline
\end{tabular}

Test compounds were given by gastric gavage at the same time as praseodymium $(10 \mathrm{mg} / \mathrm{kg}$, i.v. $)$. Liver damage was evaluated $48 \mathrm{hr}$ after dosing. Each value represents the mean $\pm \mathrm{S}$.E. for 12 rats. ${ }^{* *} \mathrm{P}<0.01$ vs. praseodymium group, Dunn's t-test. The doses producing a $50 \%$ reduction ( $\mathrm{ED}_{50}$ values) of the rise in ASAT and ALAT were interpolated from log dose-effect plots calculated by weighed least squares regression. Numbers in brackets indicate $95 \%$ confidence limits. 


\section{Effect against ethanol-induced damage in rats}

A single oral dose of ethanol $(6 \mathrm{~g} / \mathrm{kg})$ induced a significant increase in liver triglycerides, whereas liver weight and serum triglycerides did not differ significantly from those observed in non-intoxicated rats. Isocaloric treatment with glucose did not modify hepatic triglycerides.

Silipide, given at doses ranging from 100 to 400 $\mathrm{mg} / \mathrm{kg}$ (as silybin) for five repeated administrations, antagonized dose-dependently the accumulation of triglycerides in the hepatic tissue (Table 3). The calculated $E_{50}$ value was $148(81-273) \mathrm{mg} / \mathrm{kg}$ (as silybin).

Silybin (200 or $400 \mathrm{mg} / \mathrm{kg}$ ) and phosphatidylcholine (320 and $640 \mathrm{mg} / \mathrm{kg}$, which correspond to the amounts contained in the active doses of the complex) did not show any protective activity.

\section{Effect against galactosamine-induced liver damage}

A single dose of GalN $(500 \mathrm{mg} / \mathrm{kg})$ by the intraperitoneal route induced a significant increase in ASAT and ALAT activities.

Silipide, given by gastric gavage at doses of 400 and $800 \mathrm{mg} / \mathrm{kg}$ (as silybin) $4 \mathrm{hr}$ before and $4 \mathrm{hr}$ after GalN, antagonized the GalN-induced increases in ASAT and ALAT activities by about 50 and $70 \%$, respectively. The reduction obtained with the higher dose was statistically significant (Table 4 ).

Silybin (400 and $800 \mathrm{mg} / \mathrm{kg}$ ) and phosphatidylcholine (640 and $1280 \mathrm{mg} / \mathrm{kg}$ ) did not show any significant protective activity against GalN-induced liver damage.

Table 3. Effects of silipide, silybin and phosphatidylcholine against ethanol-induced liver damage in rats

\begin{tabular}{|c|c|c|c|c|c|}
\hline \multirow{3}{*}{ Treatment } & \multirow{3}{*}{$\begin{array}{c}\text { Dose } \\
\mathrm{mg} / \mathrm{kg} \times 5 \\
\text { p.o. }\end{array}$} & \multirow{3}{*}{$\begin{array}{c}\text { Serum } \\
\text { Triglycerides } \\
\mathrm{mg} / 100 \mathrm{ml}\end{array}$} & \multicolumn{2}{|c|}{ Liver } & \multirow[b]{2}{*}{ erides } \\
\hline & & & Weight & Trigl & \\
\hline & & & $\mathrm{g}$ & $\mathrm{mg} / 100 \mathrm{~g}$ & $\mathrm{ED}_{50} \mathrm{mg} / \mathrm{kg}$ \\
\hline Controls + Water & - & $82.5 \pm 6.4$ & $5.37 \pm 0.19$ & $2370 \pm 175$ & \\
\hline Controls + Glucose & - & $89.6 \pm 5.9$ & $5.23 \pm 0.14$ & $2377 \pm 408$ & \\
\hline Controls + Ethanol & - & $115.1 \pm 11.6$ & $5.81 \pm 0.12$ & $3802 \pm 439^{\mathrm{a}}$ & \\
\hline \multirow[t]{3}{*}{ Silipide (as silybin) + Ethanol } & 100 & $118.6 \pm 7.7$ & $6.05 \pm 0.19$ & $3447 \pm 472$ & \\
\hline & 200 & $106.0 \pm 9.7$ & $5.71 \pm 0.08$ & $2745 \pm 329$ & 148 \\
\hline & 400 & $100.8 \pm 6.8$ & $6.04 \pm 0.11$ & $2370 \pm 243^{b}$ & $(81-273)$ \\
\hline \multirow[t]{2}{*}{ Silybin + Ethanol } & 200 & $106.1 \pm 5.3$ & $5.91 \pm 0.14$ & $3572 \pm 425$ & \\
\hline & 400 & $185.8 \pm 46.6$ & $6.21 \pm 0.13$ & $4341 \pm 473$ & \\
\hline \multirow[t]{2}{*}{ Phosphatidylcholine + Ethanol } & 320 & $110.1 \pm 6.7$ & $5.68 \pm 0.21$ & $4890 \pm 945$ & \\
\hline & 640 & $113.9 \pm 9.8$ & $6.10 \pm 0.22$ & $3967 \pm 741$ & \\
\hline
\end{tabular}

Test compounds were given by gastric gavage twice daily for two days and once on the third day, the last dose being given $1 \mathrm{hr}$ before the oral administration of ethanol $(6 \mathrm{~g} / \mathrm{kg})$. Liver damage was evaluated $24 \mathrm{hr}$ after ethanol. Fach value represents the mean $\pm S$.E. for 10 rats. $a=P<0.05$ vs. water controls, $b=P<0.05$ vs. ethanol treated group. Dunnett's $t$-test. The dose producing a $50 \%$ reduction ( $E D_{51}$ value) of the rise in liver triglycerides was interpolated from log dose-effect plots calculated by least squares regression. Numbers in brackets indicate $95 \%$ confidence limits.

Table 4. Effects of silipide, silybin and phosphatidylcholine against galactosamine (GalN)-induced liver damage in rats

\begin{tabular}{|c|c|c|c|}
\hline \multirow[b]{2}{*}{ Treatment } & \multirow{2}{*}{$\begin{array}{c}\text { Dose } \\
\mathrm{mg} / \mathrm{kg} \times 2 \\
\text { p.o. }\end{array}$} & \multicolumn{2}{|c|}{ Serum enzymes } \\
\hline & & $\begin{array}{l}\text { ASAT } \\
\mathrm{U} / 1\end{array}$ & $\begin{array}{c}\text { ALAT } \\
\mathrm{U} / 1\end{array}$ \\
\hline Controls & - & $109 \pm 16^{* *}$ & $26 \pm 2^{* *}$ \\
\hline GalN & - & $4304 \pm 602$ & $2953 \pm 433$ \\
\hline \multirow[t]{2}{*}{ Silipide (as silybin) + GalN } & 400 & $1908 \pm 261$ & $1438 \pm 215$ \\
\hline & 800 & $1180 \pm 258^{* *}$ & $849 \pm 189^{* *}$ \\
\hline \multirow[t]{2}{*}{ Silybin + GalN } & 400 & $2478 \pm 381$ & $1713 \pm 293$ \\
\hline & 800 & $2602 \pm 763$ & $1618 \pm 508$ \\
\hline \multirow[t]{2}{*}{ Phosphatidylcholine + GalN } & 640 & $2500 \pm 452$ & $1537 \pm 410$ \\
\hline & 1280 & $2747 \pm 397$ & $2078 \pm 392$ \\
\hline
\end{tabular}

The compounds were given by gastric gavage at $4 \mathrm{hr}$ before and $4 \mathrm{hr}$ after GalN $(500 \mathrm{mg} / \mathrm{kg}$, i.p.). Liver damage was evaluated $24 \mathrm{hr}$ after GalN. Each value represents the mean $\pm \mathrm{S}$.E. for 12 animals. ${ }^{* *} \mathrm{P}<0.01$ vs. GalN group, Dunn's $t$-test. 


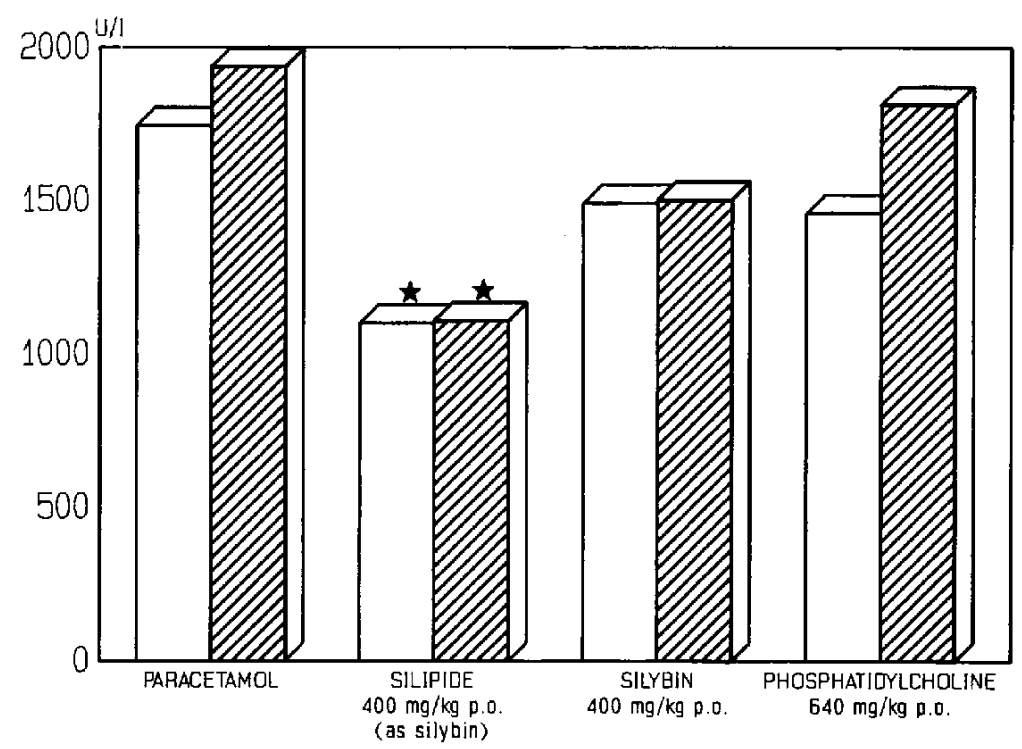

Fig. 1. Effect of silipide, silybin and phosphatidylcholine against paracetamol-induced liver damage in mice. Test compounds were given by gastric gavage $1 \mathrm{hr}$ before paracetamol $(400 \mathrm{mg} / \mathrm{kg}$, i.p.). Liver damage was evaluated $48 \mathrm{hr}$ after paracetamol. Each har represents the mean $\pm S$.E. for 20 micc. Values of serum enzymes (U/l) in non-intoxicated mice were: $90.5 \pm 7.9$ (ASAT) and $48.8 \pm 6.9$ (ALAT). ${ }^{\star} \mathrm{P}<0.05$ vs. paracetamol group, Duncan's multiple range test. $\square$ ASAT. ALAT.

Effect against paracetamol-induced liver damage in mice

A single dose of paracetamol $(400 \mathrm{mg} / \mathrm{kg})$ by the intraperitoneal route induccd a significant increase in ASAT and ALAT activities.

A single dose of silipide ( $400 \mathrm{mg} / \mathrm{kg}$, as silybin) given by gastric gavage antagonized significantly the increase in both ASAT and ALAT activities (Fig. 1).

On the contrary, silybin $(400 \mathrm{mg} / \mathrm{kg})$ and phosphatidylcholine $(640 \mathrm{mg} / \mathrm{kg})$ were devoid of any protective activity in this model.

\section{DISCUSSION}

Silipide, given by the oral route to rats at doses ranging from 25 to $800 \mathrm{mg} / \mathrm{kg}$ (as silybin), showed a significant and dose-related protective activity against liver damage induced by toxic agents with different mechanisms of action such as $\mathrm{CCl}_{4}$, praseodymium, ethanol and galactosamine. The range of doses varied according to the severity of the experimental damage and the sensitivity to the protective action of silipide. $E_{50}$ values for the inhibition of the rise in serum enzymes caused by $\mathrm{CCl}_{4}$ and praseodymium and for the antagonism of the increased hepatic triglyceride content caused by ethanol ranged from 93 to $156 \mathrm{mg} / \mathrm{kg}$ (as silybin). Silipide was also active in protecting against paracetamolinduced liver damage in mice.

Under the same experimental conditions, uncom- plexed silybin and phosphatidylcholine were devoid of any significant activity at doses equivalent to those contained in the active doses of silipide.

The protective activity of silipide against the liver damage induced by $\mathrm{CCl}_{4}$, ethanol and paracetamol could be related to its antioxidant property and inhibiting effect on membrane lipid peroxidation, believed to be involved in the damaging effect of the three xenobiotics used (6.19-21). Comoglio et al. (22) recently reported that silipide given by the oral route to rats antagonized the lipid peroxidation induced in liver microsomes by NADPH. $\mathrm{CCl}_{4}$ and cumene hydroperoxide and acted as an effective free radical scavenger towards different types of radical species. Also the activity against liver injury induced by galactosamine, which produces a damage similar to that observed in human hepatitis $(23,24)$, partly can be ascribed to the same mechanism of action. Some authors indecd reported that the damage induced by galactosamine/endotoxin can be inhibitcd by a pretreatment with the free radical scavengers (25).

A stimulating effect on the hepatic synthesis of RNA and proteins could be also involved in the silipide protective action against the decrease in liver RNA in protein synthesis caused by galactosamine (26). This stimulating effect could be also the mechanism of action underlying the protective activity of silipide against praseodymium-induced damage as reported for silybin 
(5).

The significant dose-related activities of silipide confirm that this compound is well-absorbed after oral administration in rodents, giving rise to significant plasmatic and biliary levels of silybin (12). These findings are in agrecment with those obtained by Comoglio et al. (22), who documented that the complex after oral administration to rats is able to produce an active concentration of silybin at intracellular sites of the liver. The oral efficacy of silipide and the lack of activity of the uncomplexed silybin indicate that silybin reaches active concentrations at the site of action only when administered as a complex, in agreement with the results of pharmacokinetic studies in animals and in humans $(12,27)$. Acute, sub-acute and chronic toxicity studies in rats, dogs and monkeys revealed that complexation with phosphatidylcholine does not modify the excellent tolerability of orally administered silybin (M.J. Magistretti, an unpublished study).

Favorablc results of preliminary clinical trials $(28,29)$ indicate that silipide can be considered as a promising new therapeutic agent for the treatment of hepatic disorders.

\section{Acknowledgments}

The authors are grateful to Prof. A. Crema (Head of the Medical Pharmacology Institute, University of Pavia) and to Prof. G. Pifferi (Associate Professor of Pharmaceutical Chemistry, University of Milan) for helpful discussions and criticism. The skilful technical assistance of Mr. O. Sacchi and Mr. I. Marchesini is also acknowledged.

\section{REFERENCES}

1 Salmi, H.A. and Sarna, S.: Effect of silymarin on chemical, functional, and morphological alterations of the liver. A double-blind controlled study. Scand. J. Gastroenterol. 17, $517-521(1982)$

2 Hikino, H., Kiso, Y., Wagner, H. and Fiebig, M.: Antihepatotoxic actions of flavonolignans from Silybum marianum fruits. Planta Med. 50, $248-250$ (1984)

3 Tuchweber, B., Sieck, R. and Trost, W.: Prevention by silybin of phalloidin-induced acute hepatotoxicity. Toxicol. Appl. Pharmacol. 51, 265-275 (1979)

4 Choppin, J. and Desplaces, A.: The action of silybin on the mouse liver in $\alpha$-amanitine poisoning. Arzneimittelforschung 29, 63-68 (1979)

5 Strubelt, O., Sieger, C.-P. and Younes, M.: The influence of silybin on the hepatotoxic and hypoglycemic effects of praseodymium and other lanthanides. Arzneimittelforschung 30, 1690 - 1694 (1980)

6 Campos, R., Garrido, A., Guerra, R. and Valenzuela, A.: Silybin dihemisuccinate protects against glutathione depletion and lipid peroxidation induced by acetaminophen on rat liver. Planta Med. 55, $417-419$ (1989)

7 Valenzuela, A. and Guerra, R.: Differential effect of silybin on the $\mathrm{Fe}^{2+}-\mathrm{ADP}$ and $t$-butyl hydroperoxide-induced micro- somal lipid peroxidation. Experientia 42, 139 - 141 (1986)

8 Sonnenbichler, J. and Zetl, I.: Biochemical effects of the flavonolignan silibinin on RNA, protein and DNA synthesis in rat livers. Prog. Clin. Biol. Res. 13, 319-331 (1986)

9 Lang, W.: Some aspects of silybin pharmacokinetics in the rat. In Experimentelle und Klinische Hepatologie: III $^{\circ}$ Internationales Lebersymposium, November 1978, Köln, Poster Section, Hansisches Verlags, Kontor Lübeck (1979)

10 Mennicke, W.H., Lang, W. and Lorenz, D.: Untersuchungen zur Pharmakokinetik von Silymarin. In Hepatology, Rapid Literature Revicw V-1979, p. 411, Falk Foundation, Freiburg/ Breisgau (1979) (Abs, in English)

11 Gabetta, B., Zini, G.F. and Pifferi, G.: Spectroscopic studies on IdB 1016, a new flavonolignan complex. Planta Med. 55, 615 (1989)

12 Morazzoni, P., Magistretti, M.J., Giachetti, C. and Zanolo, G.: Comparative bioavailability of IdB 1016, a new flavanolignan complex, in rats. Eur. J. Drug Metab. Pharmacokinct. 17, 39-44 (1992)

13 Torielli, M.V. and Ugazio, G.: Biochemical aspects of the protective action of propyl gallate on liver injury in rats poisoned with carbon tetrachloride. Toxicol. Appl. Pharmacol. 34, 151- 169 (1975)

14 Folch, J., Lees, M. and Sloane Stanley, G.H.: A simple method for the isolation and purification of total lipides from animal tissues. J. Biol. Chem. 226, $497-509$ (1957)

15 Baraona, E. and Lieber, C.S.: Effects of ethanol on lipid mctabolism. J. Lipid Res. 20, 289-315 (1979)

16 Pickering, R.W., James, G.W.L. and Parker, F.L.: An investigation of some parameters that affect the galactosamine model of hepatitis in the rat. Arzneimittelforschung 25, 898901 (1975)

17 Hjelle, J.J., Brzeznicka, E.A. and Klaassen, C.D.: Comparison of the effects of sodium sulfate and $\mathrm{N}$-acetylcysteine on the hepatotoxicity of acetaminophen in mice. J. Pharmacol. Exp. Ther. 236, 526-534 (1986)

18 Davis, D.C., Potter, W.Z., Jollow, D.J. and Mitchell, J.R.: Species differences in hepatic glutathione depletion, covalent binding and hepatic necrosis after acetaminophen. Life Sci. 14, $2099-2109$ (1974)

19 Letteron, P., Labbe, G., Degott, C., Berson, A., Fromenty, B., Dalaforge, M., Larrey, D. and Pessayre, D.: Mechanism for the protective effects of silymarin against carbon tetrachloride-induced lipid peroxidation and hepatotoxicity in mice. Biochem. Pharmacol. 39, 2027-2034 (1990)

20 Valenzuela, A., Aspillaga, M., Vial, S. and Guerra, R.: Selectivity of silymarin on the increase of the glutathione content in different tissue of the rat. Planta Med. 55, 420-422 (1989)

21 Valenzuela, A., Lagos, C., Schmidt, K. and Videla, L.A.: Silymarin protection against hepatic lipid peroxidation induced by acute ethanol intoxication in the rat. Biochem. Pharmacol. 34, 2209-2212 (1985)

22 Comoglio, A., Lconarduzzi, G., Carini, R., Busolin, D., Basaga, H., Albano, E., Tomasi, A., Poli, G., Morazzoni, P. and Magistretti, M.J.: Studies on the antioxidant and free radical scavenging properties of IdB 1016 a new flavonolignan complex. Frec Radic. Res. Commun. 11, 109-115 (1990)

23 Keppler, D., Lesch, R., Reutter, W. and Decker, K.: Experimental hepatitis induced by the D-galactosaminc. Exp. 
Mol. Pathol. 9, 279-290 ([968)

24 Gang, V., Baldus, M. and Kaderejt, M.: Serum level changes of endogenous and postheparin diamine oxidase (histaminase) in clinical and experimental hepatitis. Acta Hepatogastroenterol. 23, $104-109$ (1976)

25 Wendel, A., Tiegs, G. and Wemer, C.: Evidence for the involvement of a reperfusion injury in galactosamine/endotoxininduced hepatitis in mice. Biochem. Pharmacol. 36, 26372639 (1987)

26 Hirooka, S., Tanaka, T., Nogata, M., Katoh, M. and Sugimoto, T.: Effect of malotilate on hepatic injury induced by Dgalactosamine in rat. Iyakuhin Kenkyu 13, 1046-1052 (1982) (Abs. in English)

27 Barzaghi, N., Crema, F., Gatti, G., Pifferi, G. and Perucca,
E.: Pharmacokinetic studies on IdB 1016, a silybin-phosphatidylcholine complex, in healthy human subjects. Eur. J. Drug Metab. Pharmacokinet. 15, 333-338 (1990)

28 Marena, C. and Lampertico, M.: Preliminary clinical development of silipide: a new complex of silybin in toxic liver disorders. Planta Med. 57, A124-A125 (1991)

29 Buzzelli, G., Mascarella, S., Giusti, A., Marra, F., Pifferi, G., Marena, C. and Gentilini, P.: Free radical scavenging effects of silybin-phosphatidylcholine (IdB 1016) in patients with chronic liver disease, preliminary results. Abstracts of 26th Meeting "European Association for the Study of the Liver", September 1991, Palma de Mallorca (Spain), S103 (1991) 